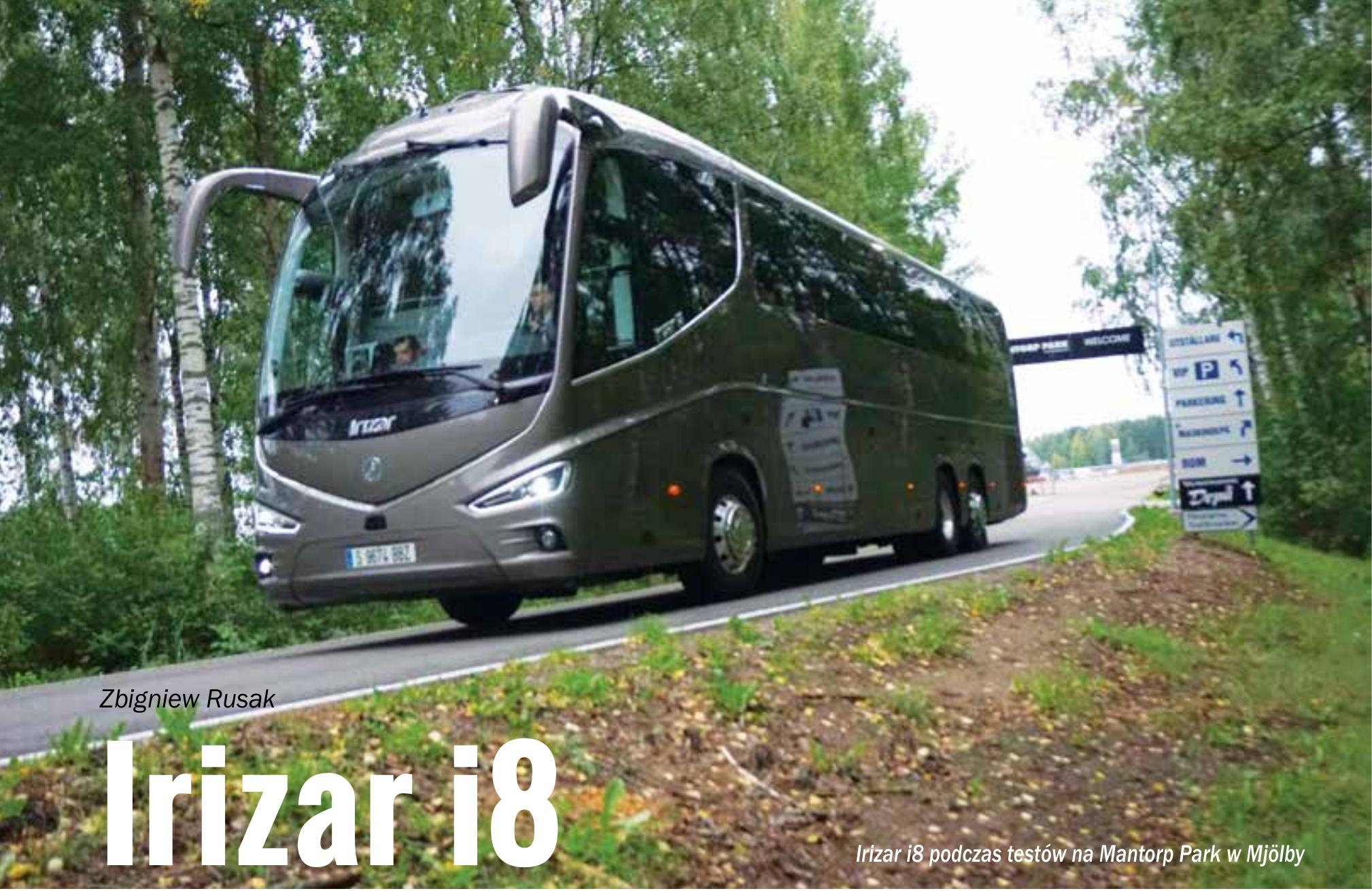

\title{
- International Coach of the Year 2018
}

W dniach od 23 do 26 maja na terenach Międzynarodowych Targów IFEMA w Madrycie miała miejsce jedna z najważniejszych tegorocznych imprez targowych - FIAA (Fiera Internacional del Autobus y del Autocar). Konstrukcje autobusów prezentowanych podczas tych targów przez koncerny ǵlobalne opisano w pierwszej części artykułu [3]. W niniejszym artykule omówiono pojazdy producentów hiszpańskich i portugalskich.

\section{Geneza modelu}

W ofercie produkcyjnej Irizara i8 zastapił znany autobusu Irizar PB, który wprowadzono do produkcji w 2001 r. Przez cały okres produkcji autokaru PB autobus wyróżniał się oryginalnym kształtem nadwozia, charakteryzującym się niskim współczynnikiem oporu aerodynamicznego. Charakterystycznymi elementami nowego nadwozia była mocno pochylona ściana przednia, zintegrowana z obudową klimatyzacji, przypominająca kształtem delfina, duża trapezowa szyba tuż za drzwiami przednimi, będąca znakiem rozpoznawczym wszystkich autobusów turystycznych Irizara oraz szeroki słupek „C”, który nie tylko pełni funkcje estetyczne, ale jest także istotnym elementem bezpieczeństwa biernego, zwiększającym sztywność nadwozia. Opływ strug powietrza został tak ukształtowany, aby zmniejszyć do minimum osadzanie się brudu na ścianach bocznych i ścianie tylnej. Odpowiednie zaokrąglenie dachu oraz ściany przedniej i tylnej zmniejszyło także podatność nadwozia na podmuchy bocznego wiatru. Przesunięcie klimatyzacji do przodu, obok poprawy wentylacji we wnętrzu pojazdu, zmieniło także rozkład nacisków na osie. Nic więc dziwne- go, że postanowiono w nowym modelu pozostawić wszystkie te elementy, które jednoznacznie identyfikują pojazd z marką Irizar. Dodatkowo w toku prac projektowych przyjęto założenie, że pojazd musi być nasycony najnowszymi rozwiązaniami technicznymi, szczególnie w zakresie bezpieczeństwa i komfortu.

Należy podkreślić, że i8 to kolejna konstrukcja integralna, opracowana w Ormaiztegi. Do połowy poprzedniej dekady oferta produkcyjna Irizara obejmowała jedynie autobusy turystyczny klasy biznes newCentury i premium PB. Jednak duża liczba wersji i opcji podwoziowych, obejmująca zarówno pojazdy dwu-, jak i trzyosiowe oraz szeroki zakres opcji wyposażenia, powodowała, że krąg odbiorców hiszpańskiego producenta był bardzo

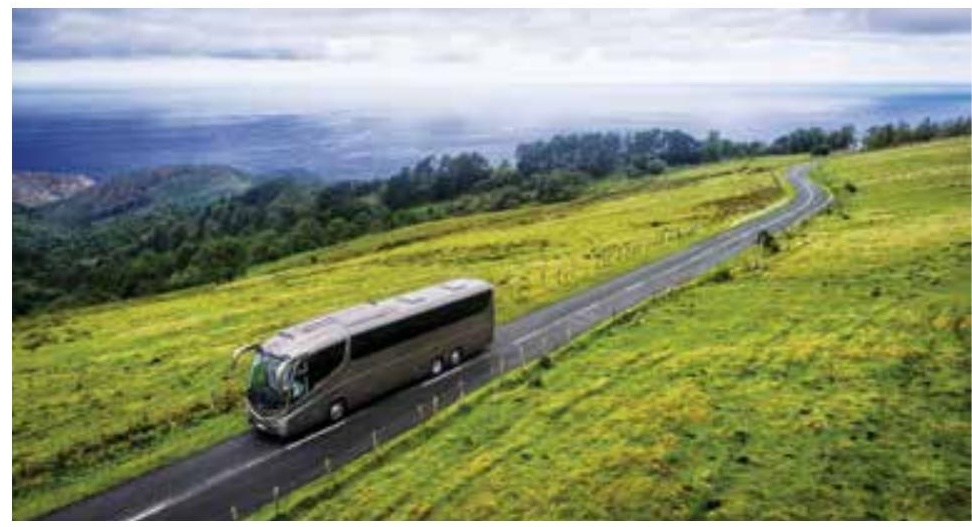

Trzyosiowy Irizar i8 nad brzegami Oceanu Atlantyckiego nieopodal San Sebastian 


\section{producenci i poddostawcy}

szeroki. Mimo to zarząd firmy poszukiwał nowych grup klientów. W 2007 r. Irizar rozpoczął produkcję autokaru klasy kombi pod oznaczeniem i4, przeznaczonego głównie do obsługi długich linii dojazdowych do dużych aglomeracji miejskich. Jest on oferowany zarówno jako autobus integralny, jak i na podwoziach Volvo, Scanii czy MAN-a. 5 lat później gama modeli Irizara została powiększona o model i3, który jest typowym autobusem podmiejskim. Wprowadzając do produkcji niskowejściowy model iße, Irizar dał znać, że zamierza płynnie wejść w sektor komunikacji miejskiej. Kolejnymi etapami tej strategii było uruchomienie produkcji elektrycznego autobusu Irizar i2e w 2014 r. oraz hybrydowych odmian autobusów klasy kombi i3h i i4h, pokazanych w 2016 r.

Zapowiedzią wprowadzenia nowej generacji autobusów turystycznych była premiera Irizara i6 podczas targów Busworld w 2009 r.; w założeniach miał on zastąpić popularny model Century. Ten ostatni, chociaż w śladowych ilościach, produkowany jest do chwili obecnej.

Aktualnie blisko 1/3 produkowanych autobusów Irizara to autobusy integralne. Irizar, jako jeden z niewielu producentów Półwyspu Iberyjskiego, z powodzeniem oparł się skutkom kryzysu gospodarczego z przełomu naszej dekady. Duży wpływ miała na to dywersyfikacja produkcji. Irizar posiada swoje fabryki produkujące autobusy, które są zlokalizowane w Hiszpanii, Meksyku, Brazylii, Indiach oraz w Północnej Afryce (Maroko) i w RPA. Pojazdy Irizara eksploatowane są w 71 krajach świata. Tradycje firmy sięgają 1889 r., kiedy to Jose Antonio Irizar uruchomił fabrykę powozów konnych. Pierwszy autobus opuścił bramy fabryki w 1929 r. Irizar zbudował w ubiegłym roku 1332 autobusy w swoich zakładach w Ormaiztegi i kolejne 1503 w fabrykach w Meksyku, Brazylii, Południowej Afryce i Maroku. 708 trafiło na rynek hiszpański, dzięki czemu Irizar kontroluje 40\% rynku w segmencie autobusów turystycznych. Obecnie na całym świecie Irizar Group zatrudnia blisko 3 tys, pracowników, w tym 700 w Hiszpanii [1].

Jak już wspomniano, nowy autobus turystyczny i8 zastąpi, po 14 latach produkcji, flagowy produkt tej firmy - model PB. Duży sukces rynkowy poprzednika zdeterminował wygląd i8. Zmiana stylistyki nadwozia, podobnie jak w przypadku i6, nastąiła ewolucyjnie. Irizar i8 jest autokarem, na bazie którego Irizar buduje swoją przyszłość w segmencie autobusów premium, przeznaczonych zarówno do obsługi regularnych linii dalekobieżnych, jak i usług o charakterze okazjonalnym. i8 to połączenie nowoczesnego designu, najnowszej technologii i zrównoważonego rozwoju. Został stworzony z myślą o zaspokojeniu potrzeb wszystkich beneficjentów: pasażerów, kierowców i operatorów. Prace rozwojowe kosztowały blisko $20 \mathrm{mln}$ euro. W porównaniu z PB w i8 zwiększono pojemność bagażników i całkowicie przeprojektowano wnętrze, wprowadzając nowe stanowisko kierowcy, płaską podłogę na całej powierzchni przestrzeni pasażerskiej, nowe siedzenia pasażerskie, zaprojektowane specjalnie dla i8, i całkowicie nowy system oświetlenia wnętrza. Dla poprawy komfortu pracy kierowcy standardem stały się takie elementy, jak aktywny tempomat, system LGS czy czujnik deszczu, automatycznie uruchamiający wycieraczki.

Premiera autobusu miała miejsce 2 lata temu podczas targów Busworld w 2015 r. Mimo prestiżowego charakteru tego modelu, do rąk tour-operatorów trafiło już łącznie ok. 1000 pojazdów tego typu, w tym 200 w Europie. Wśród nich są także 4 egzemplarze sprzedane na rynku polskim.

\section{Nadwozie}

Design i8 jest charakterystyczny dla całej rodziny pojazdów budowanych w Ormaiztegi, dla których najbardziej charakterystycznymi

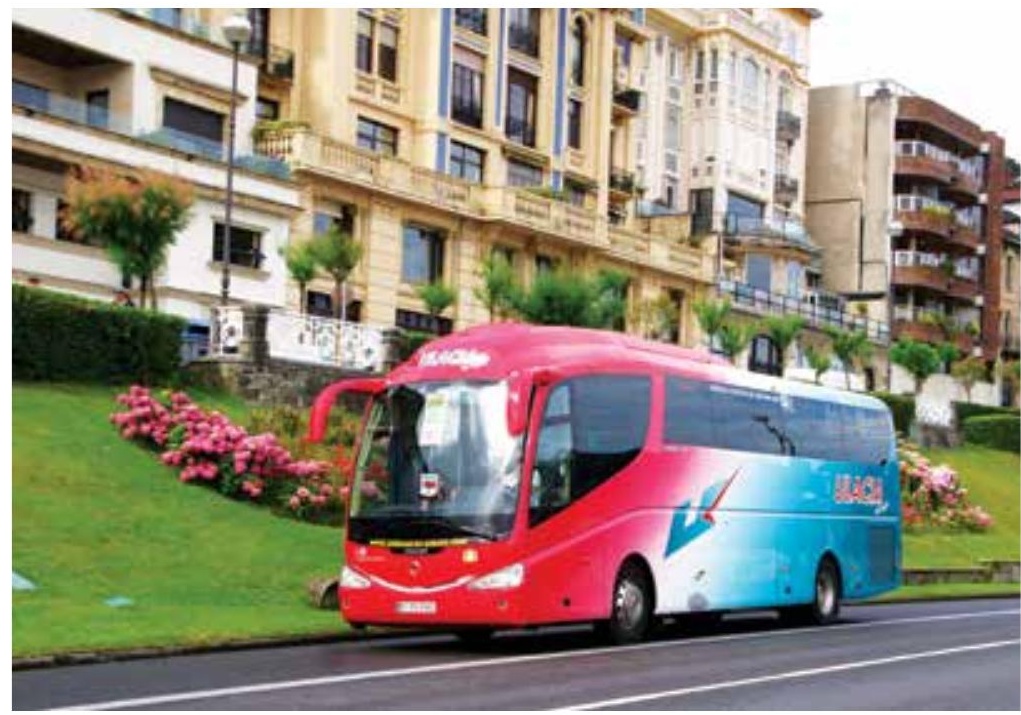

Poprzednik Irizara i8 - model PB produkowany w latach 2001-2016

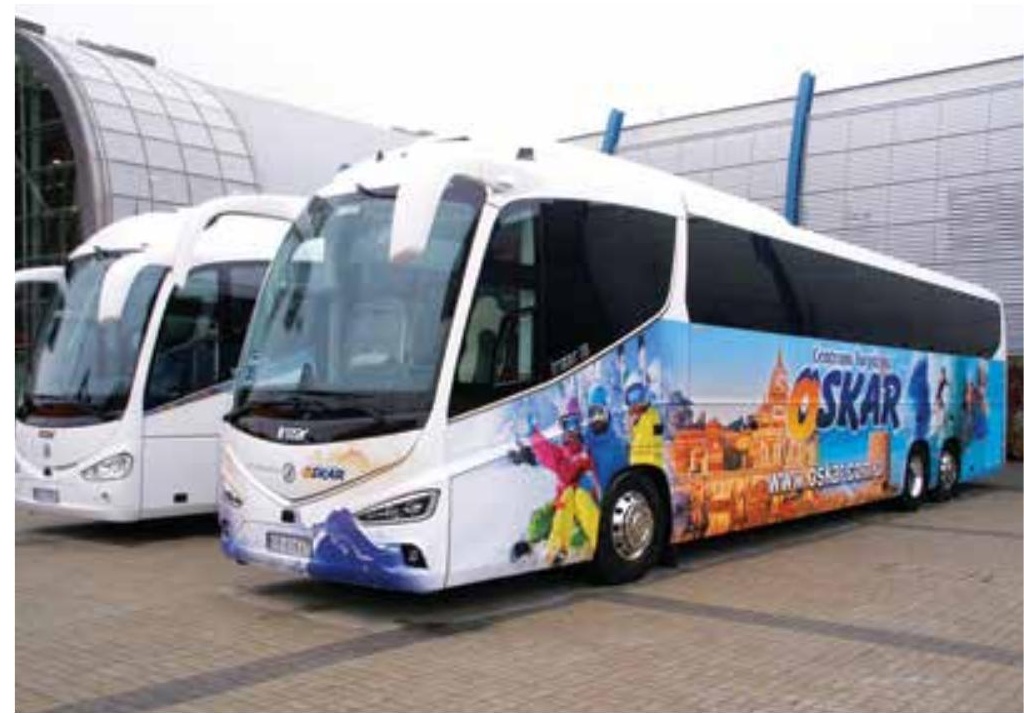

Irizar i8 w barwach biura turystycznego Oskar z Poznania

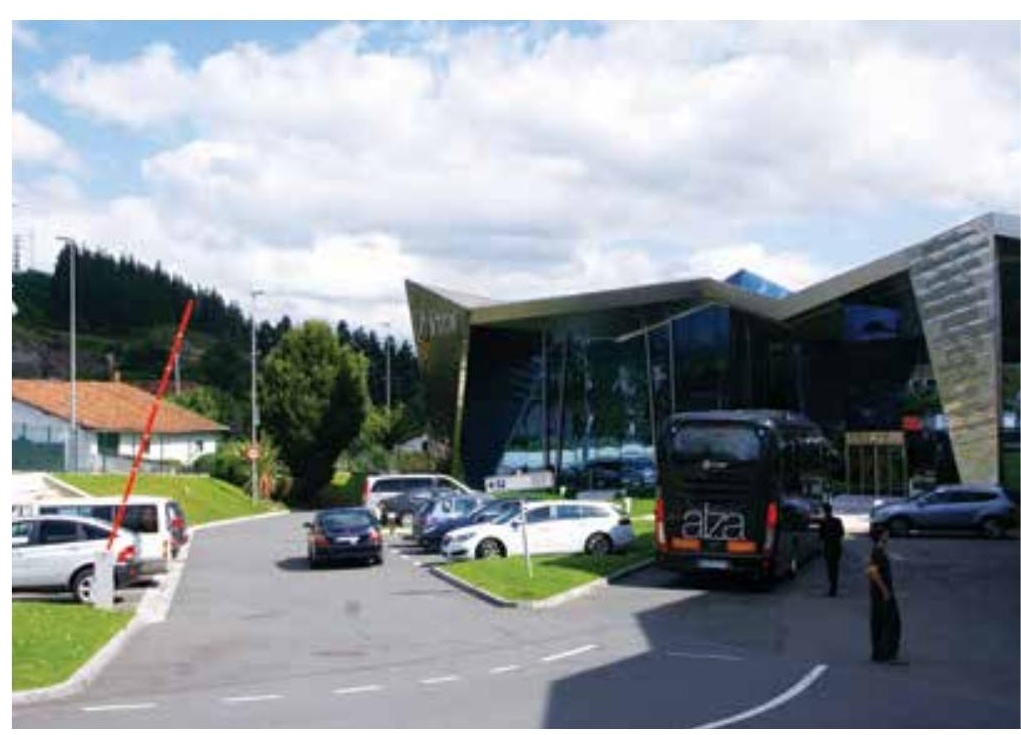

Wejście do fabryki Irizara w Ormaiztegi 


\section{producenci i poddostawcy}
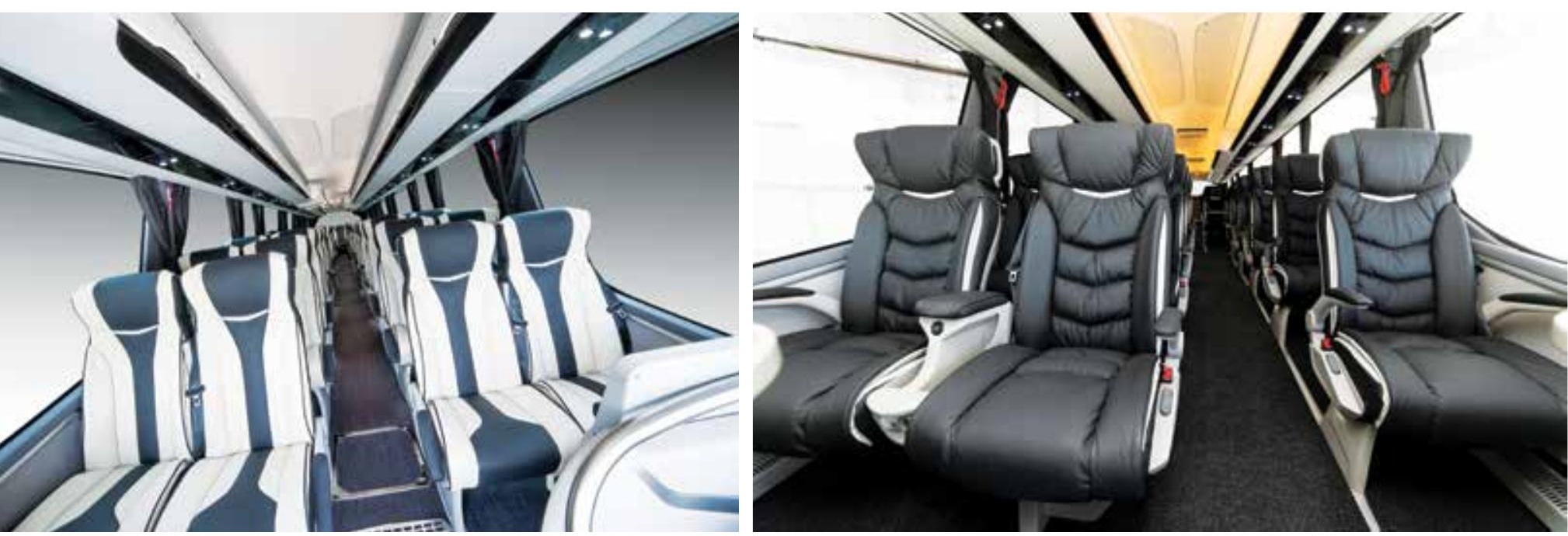

Porównanie aranżacji wnętrza przy układzie siedzeń 2 + 2 i 2 + 1

śnie odporne na zużycie. W maksymalny sposób starano się wykorzystać naturalne materiały, takie jak drewno, zamsz i - opcjonalnie - skórę.

Obszerne wnętrze o wysokości 2,01 m pozwala swobodnie poruszać się pasażerom wewnątrz pojazdu i bez problemów zajmować miejsca siedzące, nawet te znajdujące się bezpośrednio koło okna. Ciekawie zaprojektowano półki bagażowe na bagaż podręczny, które zintegrowano z monitorami LCD i zaopatrzono w elektroniczne oznaczenie numeru fotela. Opcjonalnie w pojeździe mogą być zabudowane półki z zamykanymi pokrywami. Wzdłuż dolnej powierzchni półki poprowadzono szeroką, polerowaną listwę, której integralnym elementem są oryginalne, podświetlane niebieskimi diodami LED, panele pasażera z indywidualnymi nawiewami, oświetleniem i przyciskiem przywołania.

W przestrzeni pasażerskiej zamontowano wysokie fotele zapewniające podróżnym wysoki stopień komfortu. Fotele, spełniające normy ECE-R80, ECE R-16 i ECE R-14, wyposażono w dwu- i trójpunktowe pasy bezpieczeństwa. Na życzenie klienta każdy z foteli może zostać wyposażony w pasy trójpunktowe. Na tapicerce każdego z foteli wszyto aplikację z nazwą firmy. Fotele ukształtowano tak, aby każdy z pasażerów miał wystarczającą przestrzeń, pozwalającą odprężyć się, swobodnie czytać książ- kę oraz oglądać film lub widoki przed autobusem wyświetlane na monitorach LCD. W standardowym wyposażeniu znajduje się czteropozycyjny, składany podnóżek oraz boczny przesuw foteli. Każda para foteli została wyposażona w indywidualne gniazda USB, dzięki którym można podładować w czasie podróży telefon lub tablet. Niemniej ich lokalizacja jest problematyczna. Zespół 2 gniazd zamontowany jest pod dolną krawędzią siedzeń, co wymaga wkładania wtyczki na wyczucie. W tylnym rzędzie zamontowano także dodatkowe złącza $220 \mathrm{~V}$, umożliwiajace naładowanie komputera. Opcjonalnie możliwy jest montaż gniazdek elektrycznych przy każdym rzędzie foteli.

We wnętrzu zamontowano 4 monitory LCD o przekątnej 22" (w przedniej części pojazdu) i 19". Nie zostały one zamontowane w suficie, lecz zostały wkomponowane w półki bagażowe, co upraszcza ich konstrukcję i nie naraża pasażerów na uderzenie się w głowę w przypadku ich nieschowania na postoju. Monitory połączone są z odtwarzaczem DVD, satelitarnym systemem lokalizacji GPS, wyświetlającym aktualną pozycje pojazdu na mapie, oraz z kamerą pilota, kamerą kierowcy i kamerą drogi. Opcjonalnym wyposażeniem jest montaż indywidualnych monitorów LCD, bezpośrednio w oparciach poprzedzających foteli. Oczywiście standardem w nagrodzonym autobusie jest także łączność Wi-Fi.
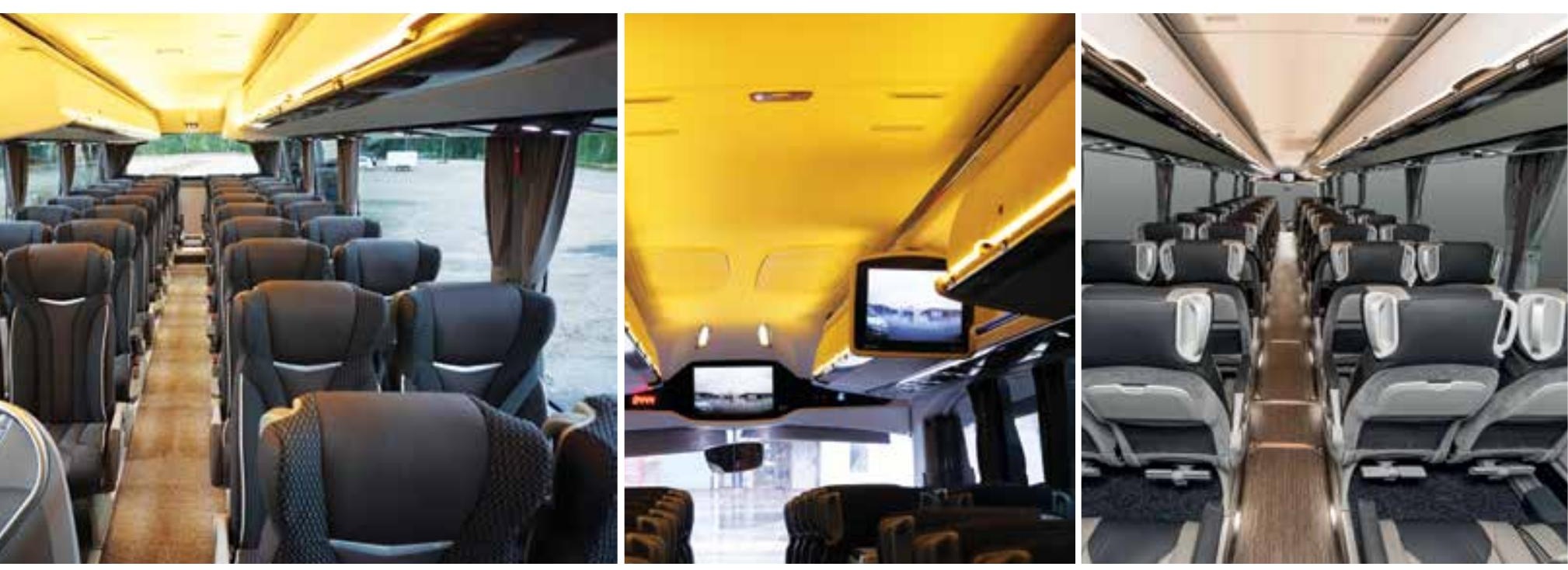

We wnętrzu starano się wykorzystać maksymalnie naturalne materiały 


\section{producenci i poddostawcy}

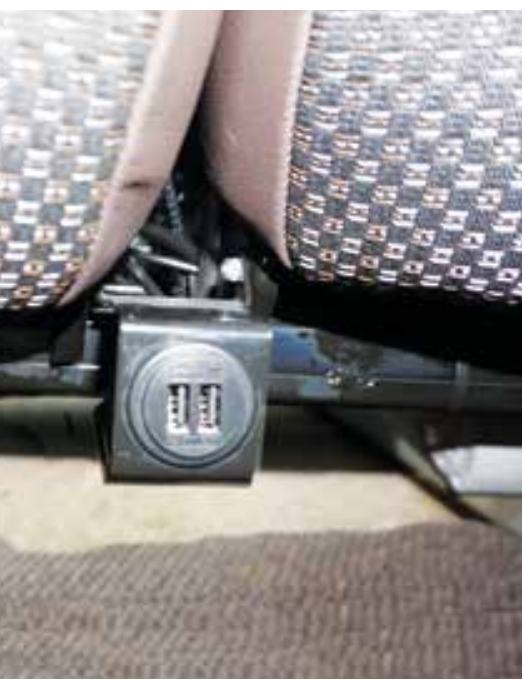

Gniazda USB umożliwiają korzystanie z telefonów i tabletów nawet na długich trasach

Toaleta, w zależności od preferencji klientów, może być zamontowana klasycznie przy środkowym wejściu, jak również w tylnej części pojazdu.

Oświetlenie wnętrza realizowane jest przy pomocy 2 linii świetInych LED, świecących światłem odbitym, poprowadzonych wzdłuż półek bagażowych. Dodatkowo, wzorem rozwiązań stosowanych w samolotach pasażerskich, pod każdym fotelem pasażerskim zamontowano diody LED, oświetlające korytarz przestrzeni pasażerskiej przy wyłączonym oświetleniu głównym.

Odpowiednie warunki termiczne w przestrzeni pasażerskiej realizowane są za pomocą grzejników konwektorowych i nawiewu z agregatu klimatyzacyjnego, zamontowanego na dachu pojazdu, o mocy 35,5 kW. Wydajność klimatyzacji zwiększono o 15\% dzięki nowo zaprojektowanemu układowi poboru powietrza. Klimatyzacja posiada dwustrefowe sterowanie umożliwiające niezależne ustawienie temperatury na stanowisku kierowcy i w przestrzeni pasażerskiej. Cały układ wentylacji i ogrzewania zapewnia także homogeniczny rozkład temperatury w całym wnętrzu przestrzeni pasażerskiej.

W ramach opcji w i8 ponad osią napędową lub wleczoną można zabudować dodatkowe drzwi, umożliwiające wprowadzenie do wnętrza wózka inwalidzkiego. Drzwi są otwierane ręcznie i zostały wyposażone w elektrycznie podnoszoną windę, która w pozycji złożonej chowa się całkowicie w przestrzeni bagażowej, bezpośrednio pod drzwiami.

Na komfort podróży pasażerów mają także wpływ rozwiązania techniczne zastosowane w podwoziu - takie, jak niezależna oś przednia ZF czy pneumatyczne zawieszenie z elektroniczną regulacją położenia. Charakterystyka pneumatycznego zawieszenia została tak dobrana, aby przy zachowaniu maksimum komfortu zapewnić odpowiednią stabilność jazdy. Po osiągnięciu prędkości $70 \mathrm{~km} / \mathrm{h}$ zawieszenie automatycznie obniża się o około $5 \mathrm{~cm}$, aby zmniejszyć opór powietrza.

\section{Stanowisko kierowcy i pilota}

Równie ciekawie zaaranżowano nowe stanowisko kierowcy. Po prawej stronie deski zaprojektowano centralny kokpit z 7-calowym ekranem dotykowym, służący zarówno kierowcy, jak i pilotowi do obsługi zintegrowanego systemu audio-video, klimatyzacji i nawigacji satelitarnej. Cała deska rozdzielcza została zaprojektowana tak, aby wszystkie kontrolki i włączniki były w zasięgu ręki kierowcy - bez konieczności zmiany jego pozycji za kierownicą. Na powierzchni deski pogrupowano elementy sterujące według funkcji i każdą grupę umieszczono w oddzielnej sekcji. Dla podkreślenia prestiżu każdą z sekcji przycisków otoczono srebrną listwą. Srebrne pierścienie otaczają także indywidualne nawiewy na desce rozdzielczej. Srebrne elementy wykończeniowe połączono ze skórzanym obiciem multifunkcyjnej kierownicy. Większość przełączników wykorzystywanych na postoju lub przy zatrzymaniu pojazdu zlokalizowano po lewej stronie fotela kierowcy. Te czę- ściej używane zlokalizowano tuż pod prędkościomierzem i obrotomierzem oraz po prawej stronie ponad ekranem HMI. Sterowanie pracą systemu GPS, audio-video, wentylacji i telefonu odbywa się za pomocą ekranu dotykowego lub centralnego pokrętła z klawiszami funkcyjnymi, zlokalizowanych po prawej stronie. Ponadto tuż pod sterownikiem HMI zamontowano łatwo dostępny ta-

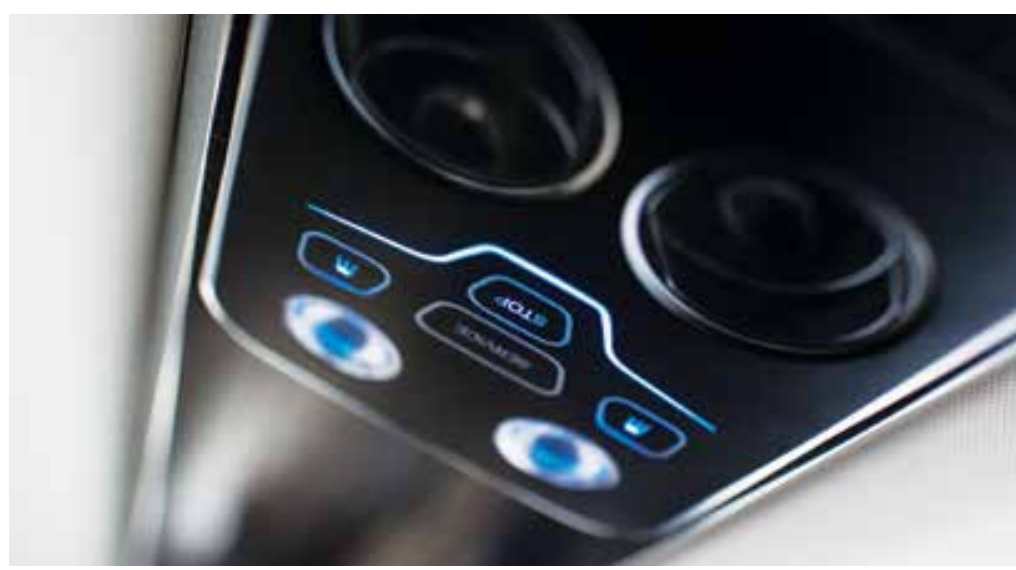

Indywidualny panel pasażera z podświetleniem typu LED

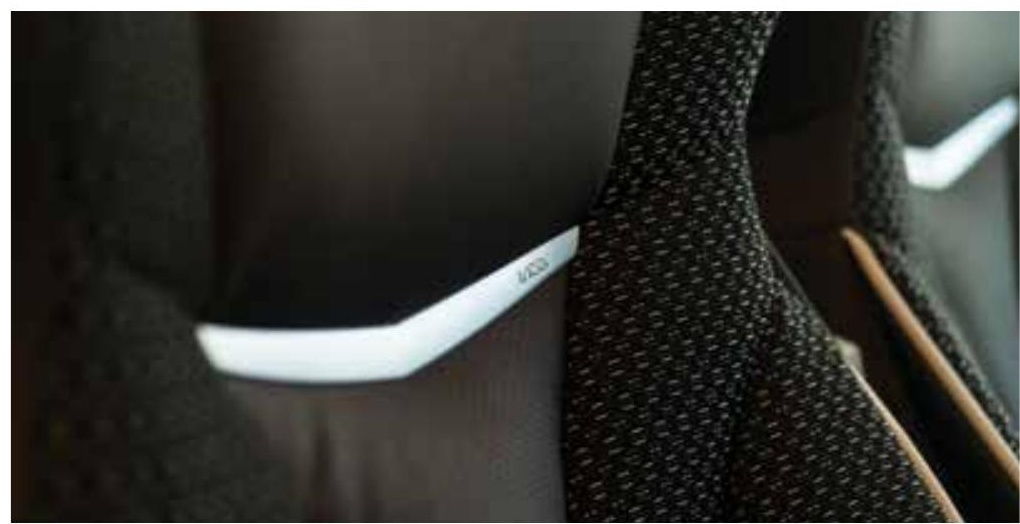

U podstawy zagłówka foteli pasażerskich, wyposażonych w dwu- lub trójpunktowe pasy bezpieczeństwa, umieszczono charakterystyczną aplikację w kształcie litery V z napisem „Irizar”

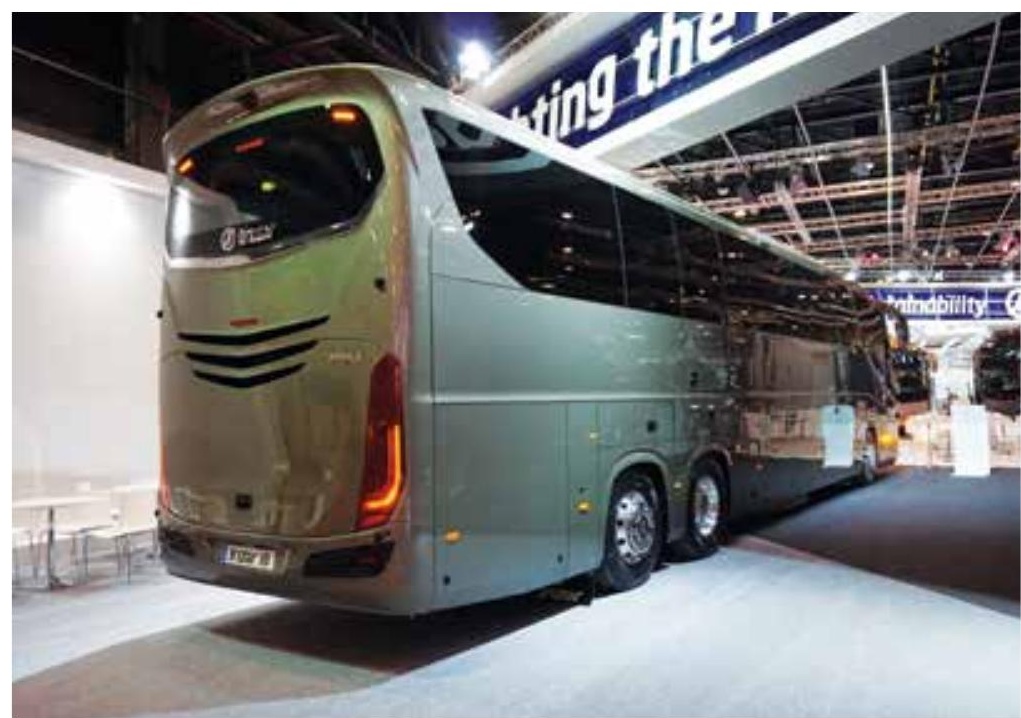

Dostęp do wnętrza osobom niepełnosprawnym, poruszającym się na wózku, umożliwiają dodatkowe drzwi, wyposażone w elektryczną windę, chowaną w luku bagażowym 


\section{producenci i poddostawcy}

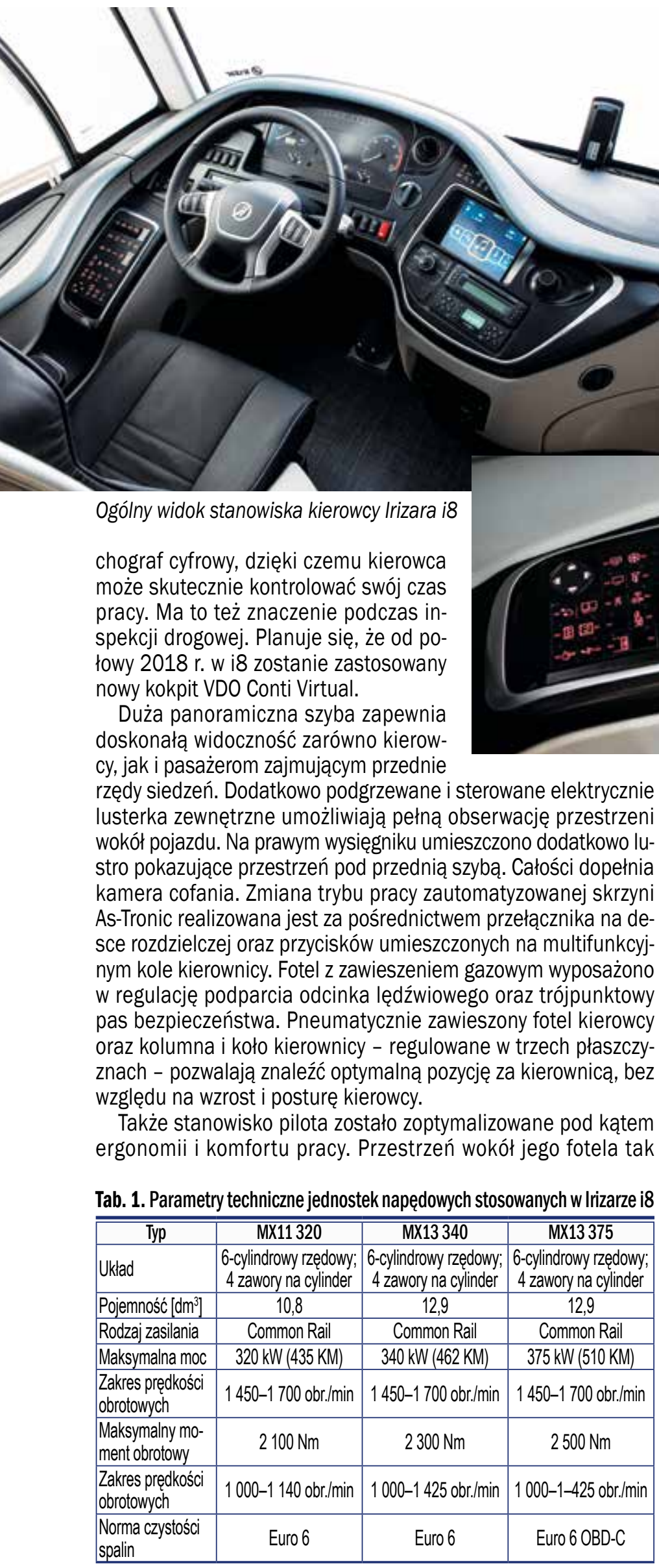

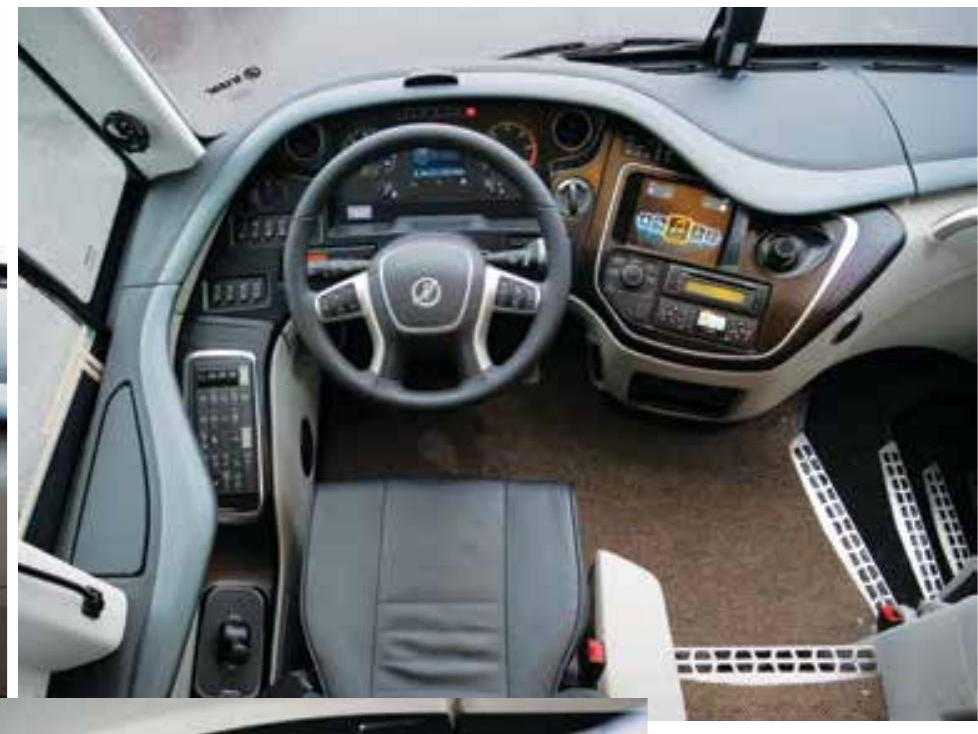

Ogólny widok stanowiska kierowcy Irizara i8

chograf cyfrowy, dzięki czemu kierowca może skutecznie kontrolować swój czas pracy. Ma to też znaczenie podczas in-

Duża panoramiczna szyba zapewnia doskonałą widoczność zarówno kierowcy, jak i pasażerom zajmującym przednie rzędy siedzeń. Dodatkowo podgrzewane i sterowane elektrycznie . stro pokazujace przestrzeń pod przednia szybą. Całości dopełnia kamera cofania. Zmiana trybu pracy zautomatyzowanej skrzyn a mika na denym kole kierownicy. Fotel z zawieszeniem gazowym wyposażono w regulację podparcia odcinka lędźwiowego oraz trójpunktowy pas bezpieczenstwa. Pneumatycznie zawieszony fotel kierowcy (ech plaszyzzgledu na wzrost i posture kierowcy.

Także stanowisko pilota zostało zoptymalizowane pod katem

Tab. 1. Parametry techniczne jednostek napędowych stosowanych w Irizarze i8

Sterowanie pracą systemu GPS, audio-video, wentylacji i telefonu odbywa się za pomocą ekranu dotykowego lub centralnego pokrętła systemu HMI

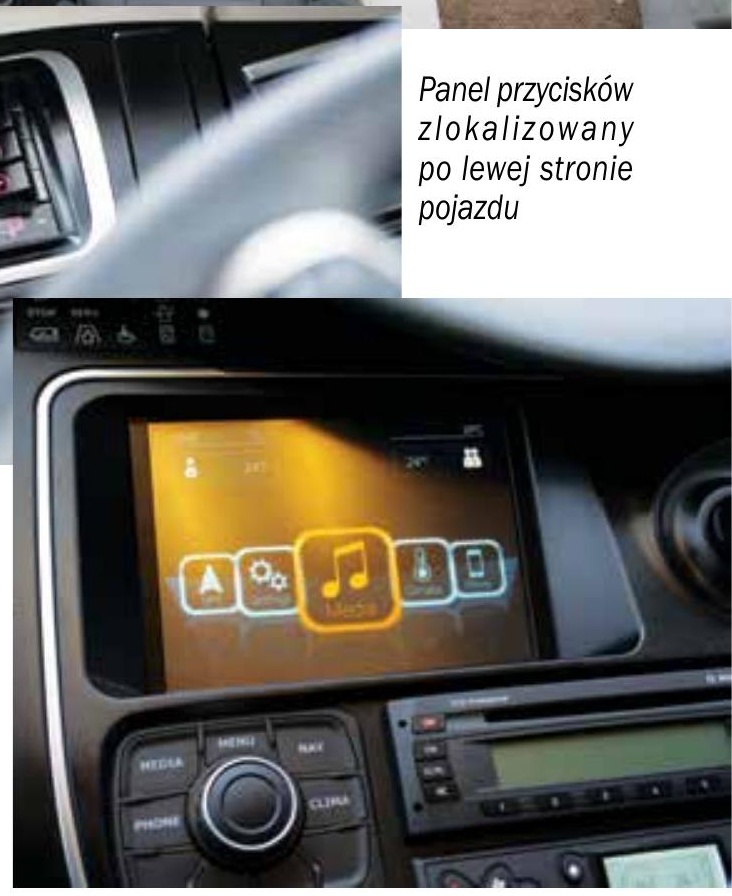

zaaranżowano, żeby podczas pracy nie musiał trzymać jakichkolwiek map czy przewodników bezpośrednio na kolanach. Naprzeciw pilota zamontowano kamerę, która przekazuje obraz jego twarzy na monitory LCD w przestrzeni pasażerskiej przy uaktywnieniu mikrofonu.

\section{Układ napędowy i jezdny}

Wszystkie integralne Irizary są napędzane silnikami DAF-PACCAR. W układzie napędu i8 zastosowano trzynastolitrowy silnik common-rail DAF MX13 o mocy 375 kW (510 KM), odznaczający się niższym o 4\% zużyciem paliwa w porównaniu z modelem PB. Osiągnięto to poprzez redukcję tarcia wewnętrznego i modyfikacje układu wtrysku paliwa. W przypadku trzyosiowego i8 zużycie paliwa wynosi około $26 \mathrm{dm}^{3} / 100 \mathrm{~km}$. W wersji 12-metrowej zużycie paliwa jest 02 I niższe. Nowa jednostka napędowa charakteryzuje się lepszą wydajnością niż jednostki poprzedniej generacji. Moc maksymalna wzrosła o 3\%, natomiast maksymalny moment obrotowy o 7\%. Silnik został zestopniowany z 12-biegową zautomatyzowaną skrzynią biegów ZF AS Tronic 12AS2700. Opcjonalnym wyposażeniem autobusu może być także 6-biegowa, w pełni au- 


\section{producenci i poddostawcy}

ustala optymalną prędkość pojazdu, w którym jest zabudowany, włączając retarder lub dławiąc silnik.

W przypadku, gdy wolniej jadący pojazd zjedzie z pasa ruchu lub przyśpieszy, prędkość autobusu jest automatycznie zwiększana do wcześniej zadanej prędkości. 0 ile przed pojazdem droga jest pusta, system działa jak konwencjonalny tempomat. Praca systemu jest aktywowana, gdy pojazd przekroczy prędkość 15 km/h.

Innymi elementami opcjonalnymi poprawiającymi bezpieczeństwo - obok adaptacyjnego tempomatu - jest system LDW (Lane Departure Warning), który alarmuje kierowcę poprzez wibrujące silniczki zainstalowane w jego siedzeniu o fakcie zjechania z wyznaczonego pasa ruchu. Także system IVTM (Integrated Vehicle Tyre pressure Monitoring), który mierzy ciśnienie w każdej oponie, zmniejsza ryzyko wystrzału, ogranicza przedwczesne zużycie opony oraz wpływa na zmniejszenie zużycia paliwa.

Opcjonalnym wyposażeniem jest także system analizujące zmęczenie kierowcy DFD (Driver Fatigue Detector), opracowany przez firmę Datik. Całości dopełniają takie elementy, jak kamery ponad środkowa klatką schodowa, kamera cofania oraz sensory deszczu i sensory automatycznej aktywacji świateł.

\section{Eksploatacja i podatność obsługowa pojazdu}

Konstruktorzy i8 starali się także, aby i8 cechował się maksymalną rentownością. Pojazd może być zdalnie diagnozowany poprzez system FMS firmy Datik, wymieniający dane za pomocą SMS-ów. Odpowiednio wcześniejsza informacja o konieczności wymiany części lub przeprowadzenia obsługi okresowej skraca czas niezbędny do jej wykonania. Zastosowanie jednostki napędowej DAF-PACCAR wydłużyło okresy międzyobsługowe silnika do 150 000 km. W porównaniu z PB obniżono koszty części serwisowych i ewentualne naprawy nadwozia. Centralny system diagnostyczny pojazdu umożliwia pełną kontrolę kosztów eksploatacji i monitorowanie zużycia poszczególnych jego komponentów. Nie bez znaczenia pozostaje także wysoka wartość końcowa pojazdu przy jego odsprzedaży. Systemy klimatyzacji i ogrzewania oraz systemy elektroniczne zostały przetestowane w specjalnych ośrodkach badawczych oraz w ekstremalnych warunkach pogodowych. Prototypy poddano specjalnym testom trwałości, odpowiadającym przejechaniu dystansu 1,5 $\mathrm{mln} \mathrm{km}$ w naturalnych warunkach.

Należy podkreślić, że spora część nowoczesnych technologii została opracowana w ośrodkach badawczo-rozwojowych wszyst-

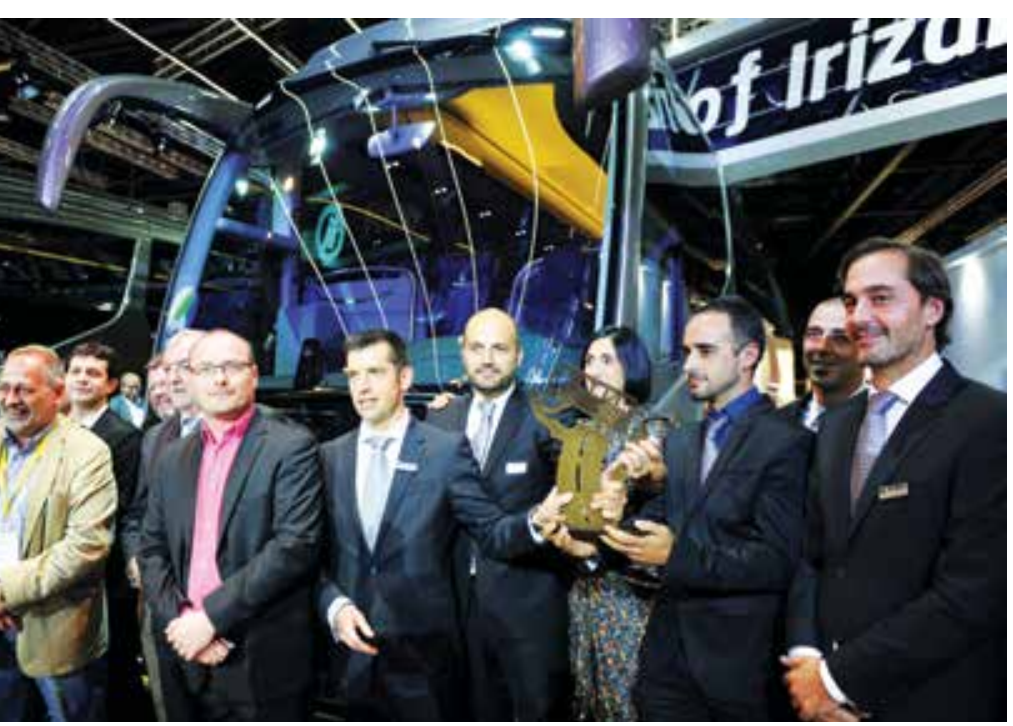

Wręczenie nagrody podczas targów Busworld Europa kich spółek wchodzących w skład Irizar Group. Przykładem może być m.in. architektura multipleksowana i protokół komunikacji CAN pomiędzy sterownikami poszczególnych komponentów, opracowany przez firmę Jema, systemy bezpieczeństwa ACC i LDW skonstruowane przez firmę Datik we współpracy z Wabco oraz detektor zmęczenia kierowcy (DFD). Jema opracowała także multipleksowy panel przełączników, nowy system nawigacji satelitarnej GPS oraz system zarządzania pracą telefonu, mediami i zintegrowanym urządzeniem grzewczo-klimatyzacyjnym za pomoca joysticka i 10-calowego ekranu dotykowego, a także innowacyjny system rozprowadzenia powietrza wewnątrz sandwichowej konstrukcji dachu.

\section{Podsumowanie}

Zwycięstwo Irizara jest drugim w historii konkursu zwycięstwem tej firmy. Pierwszy raz Irizar wspólnie z koncernem Scania zdobył tytuł International Coach of the Year w 2003 r. za autobus PB. Tym samym tytuł trafił do Hiszpanów po 14 latach przerwy. W 2011 r. Irizar i6 współzawodniczył w Coach Euro Teście, wygranym przez VDL Futura. Prestiżowa nagroda została wręczona 19 października 2017 r. na wystawie Busworld Europe w Kortrijk. Należy liczyć się, że wraz z otrzymaniem nagrody hiszpański producent nie spocznie na laurach. Jak pokazują minione 2 lata, i8, mimo wysokiej ceny, wahającej się koło 380 tys. euro, sprzedaje się doskonale na całym świecie, szczególnie w USA i Meksyku. Oznacza to, że wśród przewoźników cały czas rośnie zainteresowanie luksusowymi autobusami, mogącymi zaoferować wysoki standard podróży. W ubiegłym roku zaprezentowano po raz pierwszy autobus turystyczny z pogranicza klas premium i biznes i6s; bazując na konstrukcji popularnego i6, opracowano pojazd, w którym wykorzystano część rozwiązań z nagrodzonego i8. Ambicje Irizara nie ograniczają się jedynie do segmentu autobusów turystycznych. W 2015 r. powołano nową spółkę Irizar e-mobility, która specjalizować się będzie w produkcji autobusów elektrycznych. W roku bieżącym otwarto nową fabrykę w Aduna o zdolności produkcyjnej 1000 autobusów rocznie. Także w tym roku Irizar zaprezentował nowe niskopodłogowe autobusy miejskie z napędem elektrycznym, np. przegubową wersję i2e oraz autobus dedykowany dla systemów BRT ieTram.

Bibliografia:

1. Annual Report 2016, Irizar Group.

2. Rusak Z., Aktualne trendy rozwoju autobusów turystycznych na przykładzie testów przeprowadzonych w ramach Coach Euro Test 2017 w Linköping, „Autobusy - Technika, Eksploatacja, Systemy Transportowe" 2015, nr 11.

3. Rusak Z., Autobusowe trendy na SilesiaKomunikacja 2015, „Autobusy - Technika, Eksploatacja, Systemy Transportowe" 2015, nr 6.

4. Rusak Z., BusWorld 2015: światowe igrzyska branży autobusowej, „Autobusy - Technika, Eksploatacja, Systemy Transportowe” 2015, nr 11.

5. Rusak Z., Tuż przed Euro 6: nowe konstrukcje autobusów na 2012 rok międzynarodowych koncernów o zasięgu globalnym, „Autobusy - Technika, Eksploatacja, Systemy Transportowe" 2012, nr 3.

Autor:

mgr inż. Zbigniew Rusak - Instytut Naukowo-Wydawniczy „Spatium” w Radomiu 
Tab. 2. Dane techniczne

\begin{tabular}{|c|c|c|c|c|}
\hline Marka i typ pojazdu & \multicolumn{4}{|c|}{ Irizar i8 } \\
\hline Długość [mm] & 12400 & 13220 & 14070 & 14980 \\
\hline Szerokość [mm] & \multicolumn{4}{|c|}{2550} \\
\hline Wysokość [mm] & \multicolumn{4}{|c|}{3980} \\
\hline Układ osi & $4 \times 2$ & \multicolumn{3}{|c|}{$6 \times 2$} \\
\hline Rozstaw osi [mm] & 6265 & $6135 / 1500$ & $6335 / 1500$ & $7245 / 1500$ \\
\hline Zwis przedni [mm] & \multicolumn{4}{|c|}{2690} \\
\hline Zwis tylny [mm] & 3445 & 2895 & \multicolumn{2}{|c|}{3545} \\
\hline Maksymalna liczba miejsc & $44-51+1+1$ & $48-55+1+1$ & $52-59+1+1$ & $56-67+1+1$ \\
\hline Układ drzwi & $1-1-0$ & $1-1-0$ & $1-1-0$ & $1-1-0$ \\
\hline Pojemność bagażnika [m³] & 11,6 ( $\mathrm{z}$ toaleta) & 12,2 ( $\mathrm{z}$ toaleta) & 12,5 (z toaleta) & 13,5 (z toaleta) \\
\hline Silnik (standard) & \multicolumn{2}{|c|}{ DAF MX11-320 } & \multicolumn{2}{|c|}{ DAF MX13-340 } \\
\hline Układ & \multicolumn{4}{|c|}{ 6RTi common rail } \\
\hline Pojemność [dm³] & \multicolumn{2}{|c|}{10,8} & \multicolumn{2}{|c|}{12,9} \\
\hline Moc [ kW (KM)/rpm] & \multicolumn{2}{|c|}{$320(435) / 1450-1700$} & \multicolumn{2}{|c|}{$340(462) / 1425-1750$} \\
\hline Moment [Nm/rpm] & \multicolumn{2}{|c|}{$2100 / 1000-1450$} & \multicolumn{2}{|c|}{$2300 / 1000-1425$} \\
\hline Norma czystości spalin & \multicolumn{4}{|c|}{ Euro-6 (SCR + EGR + DPF) } \\
\hline Silnik (opcja) & - & DAF MX13-340 & \multicolumn{2}{|c|}{ DAF MX13-375 } \\
\hline Układ & - & \multicolumn{3}{|c|}{ 6RTi common-rail } \\
\hline Pojemność [ $\left.\mathrm{dm}^{3}\right]$ & - & \multicolumn{3}{|c|}{12,9} \\
\hline Moc [kW (KM)/rpm] & - & $340(462) / 1425$ & \multicolumn{2}{|c|}{$375(510) / 1500$} \\
\hline Moment [Nm/rpm] & - & $2300 / 1000-1425$ & \multicolumn{2}{|c|}{$2500 / 1000-1425$} \\
\hline Norma czystości spalin & - & \multicolumn{3}{|c|}{ Euro-6 (SCR + EGR + DPF) } \\
\hline Usytuowanie silnika & $\mathrm{R}$ & $\mathrm{R}$ & $\mathrm{R}$ & $\mathrm{R}$ \\
\hline Skrzynia biegów & $\begin{array}{c}\text { ZF As-Tronic } \\
12 \text { AS } 2100 \\
12-A\end{array}$ & $\begin{array}{c}\text { ZFAs-Tronic } \\
12 \text { AS 2100 } \\
12-A\end{array}$ & $\begin{array}{c}\text { ZF As-Tronic } \\
12 \text { AS } 2700 \\
12-A\end{array}$ & $\begin{array}{c}\text { ZFAs-Tronic } \\
12 \text { AS } 2700 \\
12-A\end{array}$ \\
\hline Retarder & ZF Intarder & ZF Intarder & ZF Intarder & ZF Intarder \\
\hline Oś przednia & $\begin{array}{c}\text { ZF RL 82 EC } \\
\text { Zawieszenie niezależne }\end{array}$ & $\begin{array}{c}\text { ZF RL 82 EC } \\
\text { Zawieszenie niezależne }\end{array}$ & $\begin{array}{c}\text { ZF RL 82 EC } \\
\text { Zawieszenie niezależne }\end{array}$ & $\begin{array}{c}\text { ZF RL 82 EC } \\
\text { Zawieszenie niezależne }\end{array}$ \\
\hline Ośśrodkowa & - & ZFA132 & ZFA132 & ZFA132 \\
\hline Ośs tylna & ZFA132 & $\begin{array}{c}\text { ZF RL 82 EC } \\
\text { Zawieszenie niezależne }\end{array}$ & $\begin{array}{c}\text { ZF RL 82 EC } \\
\text { Zawieszenie niezależne }\end{array}$ & $\begin{array}{c}\text { ZF RL 82 EC } \\
\text { Zawieszenie niezależne }\end{array}$ \\
\hline Hamulce & $\begin{array}{l}\mathrm{T} / \mathrm{T} \\
\mathrm{EBS}\end{array}$ & $\begin{array}{l}\mathrm{T} / \mathrm{T} / \mathrm{T} \\
\mathrm{EBS}\end{array}$ & $\begin{array}{l}\text { T/T/T } \\
\text { EBS }\end{array}$ & $\begin{array}{l}T / T / T \\
\text { EBS }\end{array}$ \\
\hline ABS/ASR/ESP & $S / S / S$ & S/S/S & $\mathrm{S} / \mathrm{S} / \mathrm{S}$ & S/S/S \\
\hline $\begin{array}{l}\text { Systemy bezpieczeństwa: } \\
\text { - } \text { Asystent hamowania } \\
\text { - System ciagłego hamowania } \\
\text { - Aktywne zawieszenie CDS/PVR } \\
\text { - Adaptacyjny tempomat } \\
\text { - System kontroli pasa ruchu (LDW) } \\
\text { - System monitorowania ciśnienia w ogumieniu } \\
\text { - } \text { Attention Assist (DFD) }\end{array}$ & $\begin{array}{l}S \\
S \\
S \\
S \\
S \\
S \\
0\end{array}$ & $\begin{array}{l}S \\
S \\
S \\
S \\
S \\
S \\
0\end{array}$ & $\begin{array}{l}S \\
S \\
S \\
S \\
S \\
S \\
0\end{array}$ & $\begin{array}{l}S \\
S \\
S \\
S \\
S \\
S \\
0\end{array}$ \\
\hline Rozmiar opon & $6 \times 295 / 80$ R22,5 & $8 \times 295 / 80$ R22,5 & $8 \times 295 / 80$ R22, 5 & $8 \times 295 / 80$ R22,5 \\
\hline Średnica zawracania [m] & 23,45 & 23,25 & 23,33 & 24,90 \\
\hline Pojemność zbiornika [dm³] & 670 & 670 & 670 & 670 \\
\hline Pojemność zbiornika AdBlue [dm³] & 50 & 50 & 50 & 50 \\
\hline $\begin{array}{l}\text { Wyposażenie: } \\
\text { - klimatyzacja } \\
\text { - audio/video } \\
\text { - } \text { GPS } \\
\text { - lodówka } \\
\text { - barek } \\
\text { - kuchnia } \\
\text { - WC } \\
\text { - miejsce do spania dla kierowcy } \\
\text { - szklany dach }\end{array}$ & $\begin{array}{l}S \\
S \\
S \\
S \\
0 \\
0 \\
0 \\
0 \\
-\end{array}$ & $\begin{array}{l}S \\
S \\
S \\
S \\
0 \\
0 \\
0 \\
0 \\
-\end{array}$ & $\begin{array}{l}S \\
S \\
S \\
S \\
0 \\
0 \\
0 \\
0 \\
-\end{array}$ & $\begin{array}{l}S \\
S \\
S \\
S \\
0 \\
0 \\
0 \\
0 \\
-\end{array}$ \\
\hline
\end{tabular}

